\title{
$\underline{\mathbf{P}-182}$
}

\section{Enzyme Hydrolytic Behavior of Tapioca Starch Borate Complex Under Different Storage Temperatures}

\author{
Zahid Majeed*, Nurlidia Mansor and Zakaria Man \\ Polymer Coating LabDepartment of Chemical Engineering Universiti Teknologi Petronas, Bandar Seri Iskandar, 31750 \\ Tronoh, Perak, Malaysia; Tel: +601 92958976; E-mail: zahidfdb@gmail.com
}

An important property of starch is retrogradation which affects the hydrolytic behavior towards the enzyme action. Enhancing the starch with borate increases the viscosity by reacting with the hydroxyl group of the starch which in turn changes the hydrophilicity of the starch. In the present work, starch film is prepared by using borate as gelling agent and subsequently retrograded with temperature treatment of $-10^{\circ} \mathrm{C}$ and $10^{\circ} \mathrm{C}$ and $25^{\circ} \mathrm{C}$ over a period of 15 days. Starch film treated with amylolytic enzyme extract and hydrolysis change is studied. Results of hydrolysis are supported with FTIR and TGA techniques. Rate of hydrolysis for starch film at $-10^{\circ} \mathrm{C}$ showed significant difference towards enzyme action at 24 hours compared to $10^{\circ} \mathrm{C}$ and $25^{\circ} \mathrm{C}$ treated film. Starch with borate complex improves the retrogradation of the starch film at low temperature and makes starch more susceptible to enzyme hydrolysis. TGA showed that percent weight loss were the lowest for $-10^{\circ} \mathrm{C}$ temperature treatment. The difference in decomposition temperature of retrograded starch at 10 and $-10^{\circ} \mathrm{C}$ varied from $25^{\circ} \mathrm{C}$ treatment by temperature difference of $5^{\circ} \mathrm{C}$ over the duration of study. It is concluded that starch borate complex improved retrogradation properties at low temperature which makes the film more suitable for amylolytic hydrolysis.

Keywords: TGA, FTIR, Amylases, Retrogradation, Tapioca starch borate complex. 